\title{
E-learning Environments in Academy: Technology, Pedagogy and Thinking Dispositions
}

\author{
Dan Bouhnik and Golan Carmi \\ Jerusalem College of Technology, Jerusalem, Israel
}

\author{
bouhnik@jct.ac.il carmi@jct.ac.il
}

\section{Executive Summary}

Around two decades have passed since higher education institutions began incorporating the internet as an alternative studying environment, together with frontal class teaching and learning. This kind of environment still poses meaningful challenges for students and teachers that take an active part in E-learning courses. Today it is quite clear that taking part in online courses requires new technological, behavioral, and thinking skills, in order to best handle and even successfully finish the course. Although technological skills are a must for taking part in an online course, a majority of students participating in these kinds of courses have arrived thus far without suitable prior computer experience or background, internet working skills, and internet based studies skills.

This research tests the effects of teaching and pedagogical elements in academic e-courses on the change of intellectual thinking dispositions according to the dispositional theory of Perkins, Jay and Tishman (1993). The study tested the changes that occurred in the thinking dispositions of 285 students from the Department of Information Science and the Department of Political Studies at Bar Ilan University as a result of studying in an e-learning environment. In the course of the study asynchronous and synchronous courses, which are transferred fully through the web (except for one frontal orientation meeting), were tested. The quantitative data was collected using three questionnaires in three phases. In the first phase was a 'pre-virtual course' questionnaire, which tested the seven thinking dispositions before taking an e-course. The second phase: at the end of each course a second questionnaire was distributed, which tested the seven thinking dispositions 'post virtual course'. The third questionnaire (post - part 2), also distributed at the end of the course, constituted the third phase and tested previous computer and internet knowledge and experience, further e-courses taken and the students' personal information. We found that in the ecourses there is an interactive system of relations between a number of elements that work together: the e-environment, study technologies, the teacher's activity and the teaching process and its elements. These components worked well together and brought on a change in the students' thinking dispositions in a functionally balanced and complete way. The study's results show that there is a significant statistical effect of studying in an e-environment on the changes of intellec-

Material published as part of this publication, either on-line or in print, is copyrighted by the Informing Science Institute. Permission to make digital or paper copy of part or all of these works for personal or classroom use is granted without fee provided that the copies are not made or distributed for profit or commercial advantage AND that copies 1) bear this notice in full and 2) give the full citation on the first page. It is permissible to abstract these works so long as credit is given. To copy in all other cases or to republish or to post on a server or to redistribute to lists requires specific permission and payment of a fee. Contact Publisher@InformingScience.org to request redistribution permission. tual thinking dispositions in all seven thinking dispositions. This effect is evident in the pedagogical and technological elements of e-courses, in all seven thinking dispositions, in changing levels of positive power. The conclusions of the study show that studying in an eenvironment online contributes to the change in thinking dispositions and, so, promotes intellectual thinking and behavioral patterns. 
Keywords: e-environment, thinking dispositions, e-course, virtual study

\section{Introduction}

Pedagogical processes in courses that are taught in an online environment have essential key characteristics that have an effect on the studying and teaching process. In the research literature it was found that pedagogical processes such as building, encouraging, supporting and escorting, matching a suitable pedagogical model, providing challenging interactive tasks, constructing knowledge through cooperative learning, giving detailed information, using various learning aids and materials, feedback to the point, and mutual help greatly contribute to the efficiency of the teaching process and the success of the students in the e-course (Cavanaugh, Milcovich \& Tang, 2000; Gelbart, 2000; Gunn, 2001; Insung, 2001). It was also found that understanding the changes that are needed from a lecturer in the change from frontal teaching to guiding in an eenvironment is also a factor that affects the teaching process, the studying in the course, and its outcome (Dabbagh, 2002; Easton, 2003; Fitzpatrick, 2001).

Educators and researchers believe that a lot of potential exists in e-technologies for the advancement of the student's thinking and intellectual ability. Synchronous and asynchronous hypermedia technologies (net based especially) that represent the information in different ways allow new interactions (chat, forum, e-mail, social network) that affect the learning process and its products. Computer features, in general, and the use of multimedia technologies, specifically, allow the fulfillment of brain functions and encourage activities that include partnership and intellectual creation. The ways the information is presented and represented on the computer reflect in fact the ways the brain is represented and the students thinking processes (Salomon, 2000). The hyper-text characteristic, which is used for organizing texts and electronic information items connected to the internet, changes the way the student reads and thinks (Alexander, 2004). The reference to computers as tools that allow a person to transfer, represent, and process information in new ways is being emphasized. However, the viewing of computerized technologies as a source of information alone limits their potential as a thinking tool. Therefore, a new thinking paradigm should be developed, according to which the computer expands the person's thinking abilities and helps him create new and substantial information (Resnick, 2002). In a similar way, Idan (2001) claims that e-learning isn't just about technical change but is also a cultural and social change and, particularly, a transformation in the way of thinking.

The increasing use of the internet as a studying and teaching space posts basic but essential questions that are related to the pedagogical and educational field. One of the questions, perhaps one of the most important ones, is the question of the cognitive processes that take place whilst studying in an environment full of information and technology in an e-environment. For example, in a study conducted amongst teachers and students who study teaching, the cognitive-thinking change was tested in the perception of the notion of studying as a result of experiencing the new e-environment (Mor, 2001). In another study by Rimor and Kozminsky (2003), meta-cognitive thinking processes of students in academic e-courses were tested using content analysis of reflections in the internet environment. Ben-Ami (2007) discussed in his research the question of the cognitive influences of the digital information technologies as a means of expanding and enhancing the existing abilities or as evidence for a beginning of cognitive change. In another study the effects of six different thinking styles on the learning functions, opinions, and satisfactions of the students towards e-learning were tested (Bouhnik \& Carmi, 2006).

In order to expand the academic discourse and to deepen the researched knowledge concerning the cognitive effects of e-learning, we wanted to add a research angle that hadn't been tested yet in the research literature - the thinking dispositions of the student in this environment. In the research we tested the effects of four pedagogical and technological elements that exist in every ecourse - teaching method, assignments, use of digital multimedia tools, and feedback of the 
teacher - on the change of high order intellectual thinking disposition (according to the thinking dispositions of Perkins and his colleagues (Perkins et al. 1993.

\section{Literature Review}

\section{Classification of E-courses}

The studied e-courses can be classified based on pedagogical and technological criteria. From a pedagogical aspect, the classification and sorting of the courses is done according to the analysis of the components of the teaching and learning in an e-environment process. The researcher Insung (2001) proposes analyzing the pedagogical components of e-learning based on the theory of "Transactional Distance". According to this theory there are three components that define elearning: structure - refers to responsiveness of the curriculum to the needs of the individual learner; dialog - refers to the extent of interaction enabled between the teachers and their students; learner autonomy - refers to the degree to which the learners reach decisions concerning their studies and build their knowledge based on their experiences. These three components determine the "Transactional Distance" between the teachers and the students. From a technological aspect, the classification of the courses is measured on a level of combining internet technologies in e-learning and e-teaching processes. Beller and Or (2001) demonstrate the level of internet incorporation in academic teaching using a five-level pyramid, starting from presence level to fully web level, while every level of the pyramid also includes the pedagogical implementations that were included in the former levels. Kanai (1999) sorts e-courses according to the learning processes that occur in them: courses that don't include a remote guidance element, in which the responsibility is on the hands of the student, and courses the include a "virtual teacher", in which the instructor takes part of the responsibility for the learning process, especially the coordination between the learning groups in the course. Hannum (2000) suggests a more intricate model that includes ranking in the dimension which deals with the functions of distributing the course's material online and a ranking in the dimension of the communication function that exists between the teacher and the students.

\section{Guiding Principles in E-teaching-learning}

In e-environments there are three basic components from which derive the pedagogical justification of combining the internet in the teaching and learning processes: digital technological tools for expression and creation, communication tool for forming relationships, and tools for managing information and content (Beller \& Or, 2001; Salomon, 2000; Salomon \& Perkins, 1996). However, the use of advanced teaching technologies per se doesn't assure a positive effect on studying. In order to achieve the desirable effect of studying, the use of all the representation and technological means should be planned carefully (Hannum, 2000; Insung, 2001).

The rationalization that stands at the base of the e-teaching and studying process leans on constructivist philosophical and psychological principles. The constructivist theory converts the direct delivery of knowledge implications by creating the conditions for the construction on implications by the students; it translates the teacher's understandings to the personal creation of understandings by the student. The teacher is not the main source of knowledge and doesn't even provide it, but the student is the constructor of his own knowledge in different ways, such as asking questions and collecting information, activating skills on connecting all the components. The teacher's job is to guide and enhance the students' motivation and ability to study and develop through discussion and support. "Teachers and educators should encourage students to experience the riches the world offers, they should give authorization to ask their own questions and reach their own answers and challenge them to understand the complexities that create the world" (Brooks \& Brooks, 1993). The constructivist theory in studying aspires to bring the student to a 
significant understanding of the world he lives in, although at its core this is a subjective understanding. The understanding is not automatic, and a data base that exists in the brain won't necessarily make the understanding appear. The understanding will be achieved by the student's effort to post assumptions, to research and demand, to object, view, predict, solve, generalize, and connect knowledge (Perkins, 1999; Salomon \& Perkins, 1996).

From the accumulated knowledge of the last decade, in which there was an accelerated growth of developing and teaching of e-courses, it seems that the teaching of courses initially consisted of transferring information in a faster and more convenient way, without taking into consideration current perceptions of studying and cognition. However, it seems that a change in perception has happened lately. The lack of conclusive findings in the research area, on the one hand, and the rapid expansion of the phenomena, on the other, have brought on exploration in new directions and examinations of more aspects that are connected to the integration of e-technologies in teaching and studying processes. In the last years researchers began looking at different aspects of thinking in e-environment study processes (Brett, 2006; Brunken, Plass, \& Leutner, 2003; Henry, 2006; Mayer \& Moreno, 2003; Metros \& Woolsey, 2006; Sweller, 2005; Tyler-Smith, 2006; Whipp \& Chiarelli, 2004); in a similar way related studies have also been done in Israel (Bouhnik \& Carmi, 2006; Ben-Ami, 2007; Eshet-Alkalai, 2004); Mor, 2001; Rimor \& Kozminsky, 2003; Wadmany, Rimor \& Rozner, 2011.

\section{Human Thought and Inclinations}

Human thought is based in the recognition operation system of the human organism, alongside listening, concentration, conception, understanding, remembering, forgetting, studying, and communication. It includes a combination of qualities, actions, and various traits: a complex existence with cognitive, personality, emotional, motivational, ethical, social, and cultural dimensions. Researchers and philosophers, such as Baron, Dewey, Ennis, and others (also see Baron, 1985; Dewey, 1933; Ennis, 1987; Lipman, Sharp \& Oscanyon, 1980; McPeck, 1981; Passmore, 1967; Paul, 1990; Siegel, 1988) discussed the different aspects of thinking and its components in general and, more specifically, the role of the thinking dispositions. In their use of the term "disposition" and/or related terms, such as "good habits of the mind" (Dewey, 1933) or "judgmental spirit" (Siegel, 1988), they emphasized the importance of analyzing thought from the point of view of abilities and dispositions combined. These researchers noticed that intelligent behavior is not a consequence of abilities but also of dispositions. It can be said that dispositions are behavioral tendencies: a tendency to deceit or act honestly, a tendency to be daring or careful, a tendency to set aside time for thinking, a tendency to consider wider perspectives, a tendency to search for evidence vigorously, and so on.

Theoreticians from the philosophical, psychological, and educational fields suggested theoretical structures that recognize the importance of thinking dispositions that contribute to effective thinking. Philosophers (such as Ennis, 1989; McPeck, 1981; Paul, 1990; Schrag, 1988; Siegel, 1988) and the psychologist Baron (1985) presented in their articles the centrality of the dispositions in thinking. Educators (such as Barell, 1991; Baron, 1987; Ennis, 1987) also suggested thinking disposition taxonomies that emphasize the educational importance of these dispositions. Psychological studies also show empirical evidence of the existence of certain general dispositions, such as a disposition for education i.e., Intelligence (Langer, 1989; Salomon, 1983) and more specific dispositions, such as "entity study" as opposed to "accumulated study" (Dweek \& Bempechat, 1983).

The psychological study about efficient thinking is a fertile and very active area these days (Baron, 1985; Chipman, Segal, \& Glaser, 1985; Nickerson, Perkins, \& Smith, 1985). Contemporary psychological theories suggest comprehensive models of complex cognition, dealing with thought in general (Anderson, 1983; Newell, 1990). Others deal with aspects of human intelligence, such 
as the renowned "triarchic theory of intelligence" by Sternberg (1985), which includes aspects of effective, intelligent, and high order thinking. These theories may suggest different models of intelligent thinking, but they don't deal directly with thinking dispositions.

\section{Thinking Dispositions Theory}

The thinking dispositions theory by Perkins, Jay, and Thishman (1993) emphasized the role of the dispositions in thinking. It suggests a system that includes seven basic dispositions that include all the aspects of effective thinking, which is defined as flexible, insightful, and fertile thinking. Similar to other disposition theories, this theory challenges typical thinking theories that focus on abilities (for example, Feurstein's theory (1980) and Sternberg's theory (1985)). Unlike previous dispositional views (of researchers like Barell, 1991; Baron, 1987; Ennis, 1989), Perkins, Jay, and Thishmans' theory is based upon "triadic dispositions", dispositions that are based on three foundations: impulses, sensitivities, and abilities. The theory expands the term disposition in a way that its meaning is more comprehensive and includes the threesome impulse- sensitivity - ability. The three-element model provides a basis for analysis of the thinking dispositions.

According to the theory, a disposition is a psychological element with three components: impulse, sensitivity, and ability. A disposition shows an orientation a person has towards a certain behavior. Impulse shows a drive for behaving a certain way. For example, a person with a disposition for open mindedness will feel an impulse for this kind of thinking when he sees the need for it. Sensitivity shows the awareness of a person in certain occasions; for example, a person who is sensitive to the need of open mindedness will notice the occasion in which a fear for narrow mindedness or prejudice exists. Finally, ability shows actual competence to behave in a certain way, for example, overcoming the impulse to make a hasty decision or listening to evidence that establishes different points of view. Each of the three components - impulse, sensitivity, and ability -on its own is a necessary condition for behavior; when combined they comprise adequate conditions. Without impulse a person will not feel oriented towards a certain behavior; without sensitivity a person will not recognize a certain occasion; and without the ability to perform anything it is obvious that impulse and sensitivity will not be able to make any behavioral change (Perkins et al., 1993 also see their book The Thinking Classroom, 1995).

According to Perkins and his colleagues (Perkins et al., 1993), the thinking dispositions - which are differentiated from each other and yet are interactively related to each other - are necessary elements for a wide normative characterization of effective thinking. Each one of the dispositions, when it includes the three elements of impulse, sensitivity, and ability, is essential to effective thinking. Each disposition reflects its special norm and yields rules and advice for effective thinking behavior. Likewise, the key dispositions are a functionally balanced mechanism, since they complete each other in nurturing overall effective thinking. The theory has seven key dispositions that contribute to effective, conclusive, and comprehensive thinking:

(1) Disposition to widening of horizons and adventurism;

(2) Disposition for continuous intellectual curiosity;

(3) Disposition for clarifying and striving towards understanding;

(4) Disposition for strategically thinking and planning;

(5) Disposition for intellectual cautiousness;

(6) Disposition for the search of causes or rationalization and evaluation;

(7) Disposition for meta-cognitivity.

According to Perkins and his colleagues (Perkins et al., 1993), the disposition for continuous curiosity makes the investigation persistent and constant. The disposition for intellectual cautious- 
ness minimizes errors. The disposition for strategic thinking and planning allows organized and planned thought which dictates choosing goals whilst using judgment and advises to take precautionary thinking of possible outcomes. The disposition to widening of horizons and adventurism dictates open mindedness and advises to look at things from different perspectives and come up with many possibilities. Nevertheless, the use of the disposition to widen horizons and adventurism any place and any time does not contribute to effective thinking. This disposition must be balanced with the disposition for intellectual cautiousness, disposition for the search of causes and their evaluation, and more. Hence dispositions that are used for contradicting goals can balance the others weakness and improve over time the overall thinking. The combination of all the dispositions together creates a supporting net that is greater than the sum of its parts. The fact that the dispositions complete each other improves the overall performance of the net.

In the researchers opinion, in order to nurture a disposition all three elements of the dispositional threesome must be considered, separately and together. For example, if you want to develop in students the disposition for strategic thinking and planning, the correct dispositions must be nurtured: providing the students abundant opportunities for choosing goals and making plans for themselves in meaningful contexts. In order to encourage sensitivity, you can develop sensitivity for structures of process and consequence and for cases of directionless and scattered thinking. In order to nurture strategic thinking and planning, practical strategies and rules can be taught for phrasing goals, prediction of results, and so on. Each one of these orientations involves a slightly different teaching method, but it's better to use the methods all at once to ensure that all the aspects of the dispositional threesome will merge and become one generalized thinking disposition that functions together with the rest of the dispositions (Perkins et al., 1993).

The choosing of the theory "Dispositions of Thinking" as a theoretical basis for the study was made because it is eclectic and it includes dispositions that have been discussed in three sources: analysis of dispositions (Ennis, 1989), taxonomy (Baron, 1987), and Barell's (1991) point of view. Also, the theory suggests an analytical separation of effective thinking to secondary mechanisms. It's based on logical arguments and empirical evidence for the existence and importance of dispositions. This point of view sees in the dispositions an analysis unit for a broader and more fertile understanding of thought. Moreover, it suggests a perception of the dispositions that includes a reference to habits, perceptive sensitivities, and the abilities themselves. The trivertices analysis - impulse, sensitivity, and ability - provides an insight that concerns the mechanism of each and every disposition and suggests ways to nurture the thinking dispositions.

\section{The Research Field}

The research focused on students who participated in e-courses in the B.A, and M.A. programs in two departments at Bar Ilan University: the Department of Information Science and the Department of Political Studies. Synchronous and asynchronous courses which were conducted online through the High Learn system were tested. A total of ten courses were tested, five from each de-

partment. Some of the courses taken were optional courses and some were mandatory. The testing of the courses was conducted during the course of one academic year, in the first and second semesters and also a summer semester. The courses that were tested were completely online without any frontal meetings, except for some of the courses in which the first class was frontal, for the purpose of acquaintanceship and explanation of the courses obligations, and the last class was frontal, for the purpose of summarization, feedback, and explanations concerning the exam. The pedagogical activity in all the courses that were checked was based on Insung's (2001) theory, which included three components that define e-learning: structure, dialogue, and the students' autonomy. These components were expressed in the students' self-study with the online guidance of the teachers and the practitioners through forum debates, email correspondence, and chatting in some of the courses. A wide range of teaching methods were used in the courses according to 
Hannum's (2000) model: PowerPoint presentations, Word documents, electronic Excel sheets, pictures, references to online websites or articles, online tasks with the learning system tools in the form of a test or online practicing, e-tasks that require the use of internet resources including searching, sighting and evaluating information on the internet.

\section{Research Procedure}

The testing of the sample group in the study was done in three phases using three closed questionnaires. In the first phase a 'pre-virtual course' questionnaire was given that tested the seven thinking dispositions before taking an e-course. The second and thirds phases consisted of two questionnaires at the end of each course: one tested the seven thinking dispositions 'post virtual course', and the other tested previous computer and internet knowledge and experience, further ecourses taken, and the students' personal information (post - part 2). The questionnaires were distributed to the students during the first class and the last class of every e-course in two ways: in person in class during orientation and through email. In total 350 questionnaires were handed out and 285 questionnaires were returned completed.

\section{Research Tools}

The statements in the questionnaires were phrased according to the components of Perkins and his colleagues' (Perkins et al., 1993) theoretic model. Thus, for example, the statement "while I study I can look at things from different points of view" describes the ability component for widening of horizon and adventurism disposition; "while I study I have a desire to investigate and demand" describes the impulse component of the disposition for intellectual curiosity; "while I study I'm aware of superficiality" describes the sensitivity component in the disposition for clarifying and striving towards understanding; "while I study I'm aware to the possibility of lack of precision" describes the sensitivity component in the disposition for intellectual cautiousness; "while I study I can think of a previous thought of mine" describes the ability component in the disposition for meta-cognitivity; "while I study I set goals, make plans and carry them out" describes the impulse component in the disposition for strategic thinking and planning.

The validation of the questionnaires was done by content validity and visible validity. The questionnaires were given to three researchers who checked that the statements in all three questionnaires really do test the thinking dispositions the way they are phrased in the theory, and the estudying computer and internet prior knowledge and experience. It was also checked that every disposition from the seven dispositions in the theory has a reasonable representation in the questionnaires' statements. About 98 statements that were phrased for the thinking dispositions questionnaires were corrected and changed according to feedback. In the end 76 out of them were selected. These statements were tested in an exploratory research that included 20 students, which was followed by a change in a few statements to phrase them more clearly. The high scores obtained in the coefficients of internal consistency reliability (Cronbach $\alpha$ ) also supported the questionnaires structure and content validation. The reliability test was conducted for scales (in a range of 1-6, when 1 - not at all; 6 - very much) of the thinking dispositions questionnaires at two measurement times, before and after participating in an e-course, as shown in Table 1. 
Table 1. Test results of internal consistency reliability (Cronbach $\alpha$ ) for scales of the thinking dispositions questionnaire before and after participating in the e-course

\begin{tabular}{|c|c|c|c|c|c|c|}
\hline \multirow[t]{2}{*}{$\begin{array}{l}\text { Variables / } \\
\text { Index }\end{array}$} & \multirow[b]{2}{*}{ Variables } & \multirow[t]{2}{*}{$\begin{array}{l}\text { Number } \\
\text { of items }\end{array}$} & \multirow[t]{2}{*}{$\begin{array}{c}\text { Questionnaire } \\
\text { items }\end{array}$} & \multicolumn{2}{|c|}{$\begin{array}{c}\text { Cronbach } \\
\text { alpha }\end{array}$} & \multirow[t]{2}{*}{$\begin{array}{r}\text { Values } \\
\text { reversa }\end{array}$} \\
\hline & & & & Before & After & \\
\hline $\begin{array}{l}\text { Disposition to } \\
\text { widening of ho- } \\
\text { rizons } \\
\text { and adventurism }\end{array}$ & Var1_a,c & 12 & $\begin{array}{c}, 6-3,1 \\
12,14,17-8\end{array}$ & 0.84 & 0.85 & $5,6,14$ \\
\hline $\begin{array}{l}\text { Disposition for } \\
\text { continuous } \\
\text { intellectual curi- } \\
\text { osity }\end{array}$ & Var2_a,c & 9 & $\begin{array}{c}, 2,7,13,15,16 \\
18,19,20,30\end{array}$ & 0.83 & 0.85 & \\
\hline $\begin{array}{l}\text { Disposition for } \\
\text { clarifying and } \\
\text { striving towards } \\
\text { understanding }\end{array}$ & $\operatorname{Var} 3 \mathrm{a}, \mathrm{c}$ & 13 & $, 29-21,22,24$ & 0.85 & 0.87 & \\
\hline $\begin{array}{l}\text { Disposition for } \\
\text { strategically } \\
\text { thinking and } \\
\text { planning }\end{array}$ & Var4_a,c & 10 & $, 41-23,35,36,38$ & 0.7 & 0.81 & \\
\hline $\begin{array}{l}\text { Disposition for } \\
\text { intellectual } \\
\text { cautiousness }\end{array}$ & Var5_a,c & 9 & $\begin{array}{c}, 42,45,48,49,52 \\
55,61,71,73 \\
\end{array}$ & 0.78 & 0.81 & \\
\hline $\begin{array}{l}\text { Disposition for } \\
\text { the search of } \\
\text { causes or } \\
\text { rationalization } \\
\text { and evaluation }\end{array}$ & Var6_a,c & 12 & $\begin{array}{c}, 44,50,51,54 \\
60,62,63,65-56\end{array}$ & 0.85 & 0.87 & \\
\hline $\begin{array}{l}\text { Disposition for } \\
\text { meta-cognitivity }\end{array}$ & Var7_a,c & 11 & $\begin{array}{c}, 70-53,64,66 \\
72,74,75,76\end{array}$ & 0.85 & 0.87 & 68 \\
\hline
\end{tabular}

Looking at the coefficients of reliability that are presented in Table 1 we see that in all seven measurements of the thinking dispositions, high to medium coefficients of reliability were obtained in both the measurement taken before participation in the e-course $(\alpha=0.70-0.85)$ and the one taken after $(\alpha=0.81-0.87)$. Reversal of values was done for articles 5,6 and 14 in the measurement of disposition for widening of horizons and adventurism, since they were phrased in reverse compared to other questions, whereas in the measurement of disposition for metacognitivity a value reversal was done for article 68 .

\section{Research Findings}

Based on the reliability test each participant received 14 scores ( 7 for the measurement prior to the course and 7 for the measurement after the course) of the thinking dispositions measurements. Score calculation was done by calculating the mean items of every measurement. The score ranged from 1 (a low ranking of the thinking disposition) to 6 (a high ranking of the thinking disposition). The results are shown in Table 2. 
Table 2. Mean, standard deviation, minimum and maximum in the thinking dispositions measurements before and after participating in the e-course

\begin{tabular}{|c|c|c|c|c|c|c|c|c|}
\hline \multirow{2}{*}{$\begin{array}{r}\text { Thinking Disposi- } \\
\text { tions }\end{array}$} & \multicolumn{4}{|c|}{ Before } & \multicolumn{4}{|c|}{ After } \\
\hline & Min. & Max. & $\mathbf{M}$ & SD & Min. & Max. & $\mathbf{M}$ & SD \\
\hline $\begin{array}{l}\text { Disposition to } \\
\text { widening of hori- } \\
\text { zons and adventur- } \\
\text { ism }\end{array}$ & 2 & 6 & 4.22 & 0.69 & 2.3 & 6 & 5.27 & 0.67 \\
\hline $\begin{array}{l}\text { Disposition for } \\
\text { continuous intel- } \\
\text { lectual curiosity }\end{array}$ & 1.7 & 6 & 4.13 & 0.79 & 2.4 & 6 & 5.15 & 0.83 \\
\hline $\begin{array}{l}\text { Disposition for } \\
\text { clarifying and } \\
\text { striving towards } \\
\text { understanding }\end{array}$ & 2.1 & 5.8 & 4.39 & 0.59 & 2.5 & 6 & 5.41 & 0.62 \\
\hline $\begin{array}{l}\text { Disposition for } \\
\text { strategically think- } \\
\text { ing and planning }\end{array}$ & 1.5 & 5.3 & 3.93 & 0.58 & 2.4 & 6 & 5.12 & 0.75 \\
\hline $\begin{array}{l}\text { Disposition for } \\
\text { intellectual cau- } \\
\text { tiousness }\end{array}$ & 2.7 & 6 & 4.37 & 0.6 & 3 & 6 & 5.35 & 0.62 \\
\hline $\begin{array}{l}\text { Disposition for the } \\
\text { search of causes } \\
\text { or rationalization } \\
\text { and evaluation }\end{array}$ & 1.9 & 6 & 4.17 & 0.64 & 2.4 & 6 & 5.15 & 0.69 \\
\hline $\begin{array}{l}\text { Disposition for } \\
\text { meta-cognitivity }\end{array}$ & 2.4 & 6 & 4.22 & 0.67 & 2.6 & 6 & 5.2 & 0.73 \\
\hline
\end{tabular}

Before participating in the e-course students reported in average a medium-high level of thinking dispositions, when the lowest average ranking was given to the measurement of the disposition for strategic thinking and planning (3.93), whereas the highest average ranking was given to the disposition for intellectual cautiousness (4.37) and disposition for clarifying and striving for understanding (4.39).

After participating in the e-courses, students reported on average a high-very high level of thinking dispositions, and an improvement was seen in the ranking of all measurements compared to the rankings given prior to participating in the e-courses. The lowest average ranking was given to the disposition for strategic planning and thinking (5.12), whereas the highest average ranking was given to the disposition for clarifying and striving for understanding (5.41).

\section{A. E-teaching method}

Almost half the students (46.7\%) evaluated the e-courses teaching method as medium-high, about a third $(32.3 \%)$ of the students evaluated it as very high, whereas a fifth of them $(21 \%)$ evaluated the teaching method as relatively low.

In order to check if an interaction exists between time (before participating in e-course and after) and the students' rankings of the e-course teaching method (low/medium/high) in the seven measurements of the thinking dispositions, a two-way ANOVA with repeated measurements was conducted. The dependent variables were the seven measurements of the thinking dispositions, and the independent variable was the time (testing before and after) and the students' rankings of the e-course teaching method (low/medium/high). The analysis showed that a clear simultaneous difference exists according to time and the students' ranking of the e-course teaching method $\boldsymbol{F}(\mathbf{1 4}, 552)=9.82, \boldsymbol{p}<.01, \boldsymbol{\eta}^{2}=\mathbf{2 0}$. Accordingly, the differences in relation to each one of the seven thinking dispositions measurements were tested. The averages and standard deviations of the test 
subjects according to time and the students' ranking of the e-course teaching method are presented in Table 3.

Table 3. Rankings of the thinking dispositions in the seven measurements before and after participating in the e-course, according to the students' ranking of the e-course teaching method

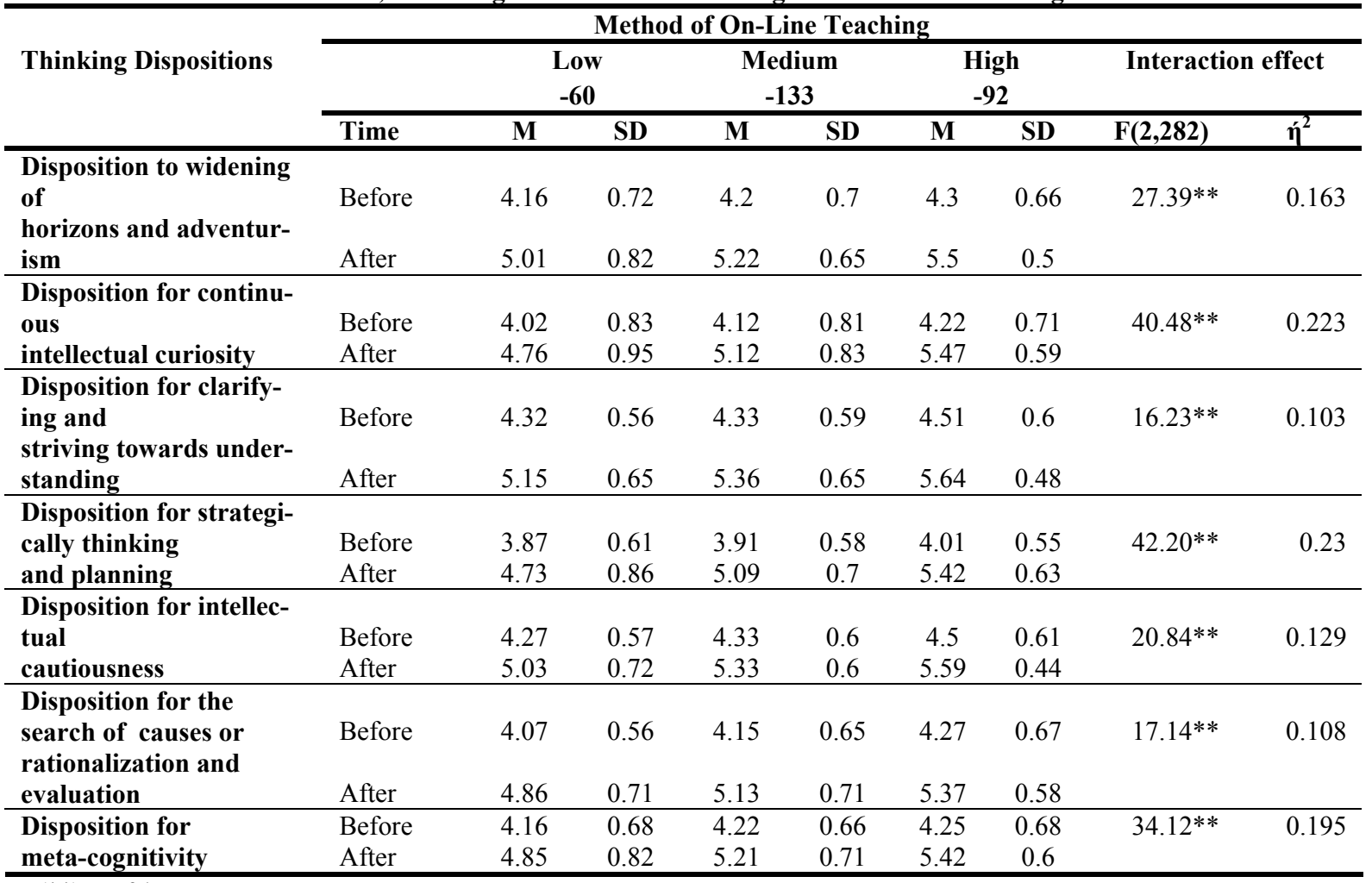

$(* *) \mathrm{p}<.01$

The findings in Table 3 show that a clear interaction of time X (Before/After) the students' ranking of the e-course teaching method exists in all seven measurements of the thinking dispositions, meaning there was a significant differential variability before the course and after it, according to the students' perception of the e-teaching method. A review of the table shows that students that gave the e-teaching method a high ranking bettered their thinking dispositions to a greater extent, compared to students that gave a lower ranking to the e-teaching method.

\section{B. Tasks and assignments}

More than half the students (52.3\%) ranked the e-course's tasks and assignments as medium-high, $29.5 \%$ gave a very high ranking, whereas $18.2 \%$ of them gave a relatively low ranking.

The testing of the interaction between time (before and after participating in an e-course) and the students' ranking of the tasks and assignments in the e-course (low/medium/high) in the seven measurements of the thinking dispositions was done using a two-way ANOVA with repeated measurements. The dependent variables were the seven measurements of the thinking dispositions; the independent variables were the time (testing before and after) and the students' rankings of the tasks and assignments in the e-course (low/medium/high). The analysis showed that a clear simultaneous difference exists according to time and the students' ranking of the e-course's tasks and assignments $\mathrm{F}(14,552)=8.50, \mathrm{p}<.01, \eta \mathbf{\eta}=.18$. Accordingly, the differences in relation to each one of the seven thinking dispositions measurements were tested. The averages and standard deviations of the test subjects according to time and the students' ranking of the e-course's tasks and assignments are presented in Table 4. 
The findings in Table 4 show that a clear interaction of time X(Before/After) the students' ranking of the tasks and assignments exists in all seven measurements of the thinking dispositions. In other words, there was a significant differential variability before the course and after it, according to the students' ranking of the tasks and assignments. A review of the table shows that students that gave the course's tasks and assignments a higher ranking bettered their thinking dispositions to a greater extent, compared to students that gave a lower ranking to the e-course's tasks and assignments.

Table 4. Rankings of the thinking dispositions in the seven measurements before and after participating in the e-course, according to the students' ranking of the tasks and assignments

\begin{tabular}{|c|c|c|c|c|c|c|c|c|c|}
\hline \multirow{3}{*}{ Thinking Dispositions } & & \multicolumn{8}{|c|}{ Assignments and learning tasks } \\
\hline & & \multicolumn{2}{|c|}{$\begin{array}{c}\text { Low } \\
-52\end{array}$} & \multicolumn{2}{|c|}{$\begin{array}{c}\text { Medium } \\
-149\end{array}$} & \multicolumn{2}{|c|}{$\begin{array}{c}\text { High } \\
-84 \\
\end{array}$} & \multicolumn{2}{|c|}{ Interaction effect } \\
\hline & Time & $\mathbf{M}$ & SD & $\bar{M}$ & SD & $\mathbf{M}$ & SD & $\mathbf{F}(2,282)$ & $\dot{\eta}^{2}$ \\
\hline $\begin{array}{l}\text { Disposition to widen- } \\
\text { ing of } \\
\text { horizons and adven- } \\
\text { turism }\end{array}$ & $\begin{array}{l}\text { Before } \\
\text { After }\end{array}$ & 4.76 & 0.75 & 4.32 & 0.66 & 4.19 & 0.68 & $37.73 * *$ & 0.211 \\
\hline $\begin{array}{l}\text { Disposition for con- } \\
\text { tinuous } \\
\text { intellectual curiosity }\end{array}$ & $\begin{array}{l}\text { Before } \\
\text { After }\end{array}$ & $\begin{array}{c}3.79 \\
4.5 \\
\end{array}$ & $\begin{array}{l}0.85 \\
0.98 \\
\end{array}$ & $\begin{array}{c}4.2 \\
5.22 \\
\end{array}$ & $\begin{array}{c}0.8 \\
0.76 \\
\end{array}$ & $\begin{array}{l}4.22 \\
5.44\end{array}$ & $\begin{array}{l}0.67 \\
0.58\end{array}$ & $36.39 * *$ & 0.205 \\
\hline $\begin{array}{l}\text { Disposition for clarify- } \\
\text { ing and } \\
\text { striving towards un- } \\
\text { derstanding }\end{array}$ & $\begin{array}{l}\text { Before } \\
\text { After }\end{array}$ & 4.27 & 0.54 & 4.36 & 0.63 & 4.52 & 0.58 & $24.74 * *$ & 0.149 \\
\hline $\begin{array}{l}\text { Disposition for strate- } \\
\text { gically thinking } \\
\text { and planning }\end{array}$ & $\begin{array}{l}\text { Before } \\
\text { After }\end{array}$ & $\begin{array}{l}3.84 \\
4.68 \\
\end{array}$ & $\begin{array}{l}0.51 \\
0.75 \\
\end{array}$ & $\begin{array}{l}3.91 \\
5.13 \\
\end{array}$ & $\begin{array}{c}0.59 \\
0.7 \\
\end{array}$ & $\begin{array}{l}4.02 \\
5.38 \\
\end{array}$ & $\begin{array}{l}0.58 \\
0.73 \\
\end{array}$ & $31.10 * *$ & 0.181 \\
\hline $\begin{array}{l}\text { Disposition for intel- } \\
\text { lectual } \\
\text { cautiousness }\end{array}$ & $\begin{array}{l}\text { Before } \\
\text { After }\end{array}$ & $\begin{array}{l}4.27 \\
4.97 \\
\end{array}$ & $\begin{array}{l}0.62 \\
0.78 \\
\end{array}$ & $\begin{array}{l}4.36 \\
5.34 \\
\end{array}$ & $\begin{array}{l}0.62 \\
0.55 \\
\end{array}$ & $\begin{array}{l}4.46 \\
5.61 \\
\end{array}$ & $\begin{array}{l}0.56 \\
0.47 \\
\end{array}$ & $34.54 * *$ & 0.197 \\
\hline $\begin{array}{l}\text { Disposition for the } \\
\text { search of causes or } \\
\text { rationalization and } \\
\text { evaluation }\end{array}$ & Before & 4.02 & 0.57 & 4.16 & 0.68 & 4.28 & 0.59 & $34.44 * *$ & 0.196 \\
\hline $\begin{array}{l}\text { Disposition for } \\
\text { meta-cognitivity }\end{array}$ & $\begin{array}{l}\text { Before } \\
\text { After }\end{array}$ & $\begin{array}{c}4.04 \\
4.7\end{array}$ & $\begin{array}{l}0.61 \\
0.78\end{array}$ & $\begin{array}{l}4.23 \\
5.21\end{array}$ & $\begin{array}{l}0.71 \\
0.72\end{array}$ & $\begin{array}{l}4.31 \\
5.49\end{array}$ & $\begin{array}{l}0.62 \\
0.51\end{array}$ & $37.84 * *$ & 0.212 \\
\hline
\end{tabular}

$\mathbf{p}(* *) \mathbf{p}<.01$

\section{Use of digital multimedia tools}

About a quarter of the students (24.2\%) gave a low ranking to the degree of use in representation and visualization tools throughout the e-course, about a third (32.6\%) gave a medium-high ranking, whereas $43.2 \%$ gave a very high ranking.

The testing of the interaction between time (before and after participating in an e-course) and the students' ranking of the degree of use in representation and visualization tools (low/medium/high) in the seven measurements of the thinking dispositions was done using a two-way ANOVA with repeated measurements. The dependent variables were the seven measurements of the thinking dispositions; the independent variables were the time (testing before and after) and the students' rankings of the degree of use in representation and visualization tools in the e-course (low/medium/high). The analysis showed that a clear simultaneous difference exists according to time and the students' ranking of the e-course's degree of use in representation and visualization tools $\boldsymbol{F}(\mathbf{1 4 , 5 5 2})=7.25, \boldsymbol{p}<\mathbf{0 1}, \boldsymbol{\eta}^{2}=\mathbf{1 6}$. Accordingly, the differences in relation to each one of the seven thinking dispositions measurements were tested. The averages and standard deviations of the test subjects according to time and the students' ranking of the e-course's degree of use in representations and visualization tools are presented in Table-5. 
The findings in Table 5 show that a clear interaction of time $\mathrm{X}$ (Before/After) the students' ranking of the degree of use in representation and visualization tools exists in all seven measurements of the thinking dispositions, meaning there was a significant differential variability before the course and after it, according to the students' perception of the degree of use in representation and visualization tools. A review of the table shows that students that gave the course's degree of use in representation and visualization tools a higher ranking improved their thinking dispositions to a greater extent, compared to students that gave a lower ranking.

Table 5. Rankings of the thinking dispositions in the seven measurements before and after participating in the e-course, according to the students' ranking of the degree of use in representation and visualization tools in the e-course

\begin{tabular}{|c|c|c|c|c|c|c|c|c|c|}
\hline \multirow{3}{*}{$\begin{array}{l}\text { Thinking Disposi- } \\
\text { tions }\end{array}$} & & \multicolumn{8}{|c|}{ Rating means of representation and visualization } \\
\hline & & \multicolumn{2}{|c|}{$\begin{array}{l}\text { Low } \\
-69\end{array}$} & \multicolumn{2}{|c|}{$\begin{array}{c}\text { Medium } \\
-93\end{array}$} & \multicolumn{2}{|c|}{$\begin{array}{c}\text { High } \\
-123\end{array}$} & \multicolumn{2}{|c|}{ Interaction effect } \\
\hline & Time & $\mathbf{M}$ & SD & $\mathbf{M}$ & SD & $\mathbf{M}$ & SD & $\mathbf{F}(2,282)$ & 'H2 \\
\hline $\begin{array}{l}\text { Disposition to wid- } \\
\text { ening of } \\
\text { horizons and ad- } \\
\text { venturism }\end{array}$ & $\begin{array}{l}\text { Before } \\
\text { After }\end{array}$ & 5.11 & 0.74 & 4.19 & 0.66 & 4.23 & $\begin{array}{l}0.67 \\
0.62 \\
\end{array}$ & $* * 28.16$ & 0.166 \\
\hline $\begin{array}{l}\text { Disposition for } \\
\text { continuous } \\
\text { intellectual curios- } \\
\text { ity }\end{array}$ & $\begin{array}{l}\text { Before } \\
\text { After }\end{array}$ & 4.03 & 0.87 & 4.12 & 0.82 & 4.2 & 0.67 & $* * 25.41$ & 0.153 \\
\hline $\begin{array}{l}\text { Disposition for } \\
\text { clarifying and } \\
\text { striving towards } \\
\text { understanding }\end{array}$ & $\begin{array}{l}\text { Before } \\
\text { After }\end{array}$ & 4.45 & 0.61 & 5.24 & 0.55 & 4.44 & $\begin{array}{r}0.6 \\
0.56 \\
\end{array}$ & $* * 12.34$ & 0.08 \\
\hline $\begin{array}{l}\text { Disposition for } \\
\text { strategically think- } \\
\text { ing } \\
\text { and planning }\end{array}$ & $\begin{array}{l}\text { Before } \\
\text { After }\end{array}$ & $\begin{array}{l}3.96 \\
4.94 \\
\end{array}$ & $\begin{array}{l}0.58 \\
0.77 \\
\end{array}$ & $\begin{array}{r}3.9 \\
5.04 \\
\end{array}$ & $\begin{array}{c}0.57 \\
0.7 \\
\end{array}$ & $\begin{array}{l}3.94 \\
5.29 \\
\end{array}$ & $\begin{array}{l}0.58 \\
0.76 \\
\end{array}$ & $* * 20.92$ & 0.129 \\
\hline $\begin{array}{l}\text { Disposition for } \\
\text { intellectual } \\
\text { cautiousness }\end{array}$ & $\begin{array}{l}\text { Before } \\
\text { After }\end{array}$ & $\begin{array}{l}4.36 \\
5.16 \\
\end{array}$ & $\begin{array}{l}0.63 \\
0.74 \\
\end{array}$ & $\begin{array}{l}4.26 \\
5.24 \\
\end{array}$ & $\begin{array}{l}0.6 \\
0.6 \\
\end{array}$ & $\begin{array}{l}4.46 \\
5.53 \\
\end{array}$ & $\begin{array}{l}0.58 \\
0.49 \\
\end{array}$ & $* * 14.84$ & 0.095 \\
\hline $\begin{array}{l}\text { Disposition for the } \\
\text { search of causes } \\
\text { or } \\
\text { rationalization and } \\
\text { evaluation }\end{array}$ & Before & 4.13 & 0.77 & 4.12 & 0.59 & 4.23 & 0.64 & $* * 13.97$ & 0.09 \\
\hline $\begin{array}{l}\text { Disposition for } \\
\text { meta-cognitivity }\end{array}$ & $\begin{array}{l}\text { Before } \\
\text { After }\end{array}$ & $\begin{array}{c}4.26 \\
5\end{array}$ & $\begin{array}{l}0.73 \\
0.81\end{array}$ & $\begin{array}{l}4.15 \\
5.11\end{array}$ & $\begin{array}{l}0.62 \\
0.73\end{array}$ & $\begin{array}{l}4.25 \\
5.38\end{array}$ & $\begin{array}{l}0.67 \\
0.63\end{array}$ & $* * 26.83$ & 0.16 \\
\hline
\end{tabular}

$(* *) \mathbf{p}<.01$

\section{Teacher's feedback}

About a quarter of the students (24.2\%) gave a relatively low ranking to the teacher's feedback, $41.1 \%$ gave a medium-high ranking, while $34.7 \%$ gave a very high ranking.

The testing of the interaction between time (before and after participating in an e-course) and the students' ranking of the teacher's feedback in the e-course (low/medium/high) in the seven measurements of the thinking dispositions was done using a two-way ANOVA with repeated measurements. The dependent variables were the seven measurements of the thinking dispositions; the independent variables were the time (testing before and after) and the students' rankings of the teacher's feedback in the e-course (low/medium/high). The analysis showed that a clear simultaneous difference exists according to time and the students' ranking of the teacher's feedback in the e-course $\boldsymbol{F}(\mathbf{1 4}, 552)=7.37, \boldsymbol{p}<.01, \boldsymbol{\eta}^{2}=.16$. Accordingly, the differences in relation to each one of the seven thinking dispositions measurements were tested. The averages and standard deviations 
of the test subjects according to time and the students' ranking of the teacher's feedback in the ecourse are presented in Table 6.

The findings in Table 6 show that a clear interaction of time X(Before/After) the students' ranking of the teacher's feedback exists in all seven measurements of the thinking dispositions. In other words, there was a significant differential variability before the course and after it, according to the students' perception of the teacher's feedback. A review of the table shows that students that gave the teacher's feedback in the course a higher ranking improved their thinking dispositions to a greater extent, compared to students that gave a lower ranking to the teacher's feedback.

Table 6. Rankings of the thinking dispositions in the seven measurements before and after participating in the e-course, according to the students' ranking of the teacher's feedback

\begin{tabular}{|c|c|c|c|c|c|c|c|c|c|}
\hline \multirow{3}{*}{$\begin{array}{l}\text { Thinking Dispo- } \\
\text { sitions }\end{array}$} & & \multicolumn{8}{|c|}{ Rating of lecturer feedback } \\
\hline & & \multicolumn{2}{|c|}{$\begin{array}{c}\text { Low } \\
-69\end{array}$} & \multicolumn{2}{|c|}{$\begin{array}{c}\text { Medium } \\
-117\end{array}$} & \multicolumn{2}{|c|}{$\begin{array}{c}\text { High } \\
-99 \\
\end{array}$} & \multicolumn{2}{|c|}{ Interaction effect } \\
\hline & Time & $\mathbf{M}$ & SD & $\mathbf{M}$ & SD & $\mathbf{M}$ & SD & $\mathbf{F}(2,282)$ & $\eta 2$ \\
\hline $\begin{array}{l}\text { Disposition to } \\
\text { widening of } \\
\text { horizons and } \\
\text { adventurism }\end{array}$ & $\begin{array}{l}\text { Before } \\
\text { After }\end{array}$ & 4.02 & 0.67 & 4.27 & 0.68 & 4.3 & 0.61 & $23.06^{* *}$ & 0.141 \\
\hline $\begin{array}{l}\text { Disposition for } \\
\text { continuous } \\
\text { intellectual curi- } \\
\text { osity }\end{array}$ & $\begin{array}{l}\text { Before } \\
\text { After }\end{array}$ & $\begin{array}{l}3.84 \\
4.67\end{array}$ & $\begin{array}{l}0.78 \\
0.87\end{array}$ & $\begin{array}{l}4.29 \\
5.28\end{array}$ & 0.72 & $\begin{array}{l}4.15 \\
5.34\end{array}$ & $\begin{array}{l}0.79 \\
0.78\end{array}$ & $21.24 * *$ & 0.131 \\
\hline $\begin{array}{l}\text { Disposition for } \\
\text { clarifying and } \\
\text { striving towards } \\
\text { understanding }\end{array}$ & $\begin{array}{l}\text { Before } \\
\text { After }\end{array}$ & $\begin{array}{l}4.29 \\
5.21\end{array}$ & 0.46 & $\begin{array}{l}4.43 \\
5.43 \\
\end{array}$ & $\begin{array}{l}0.6 \\
0.65 \\
\end{array}$ & $\begin{array}{l}4.41 \\
5.51\end{array}$ & $\begin{array}{l}0.66 \\
0.61\end{array}$ & $6.87 * *$ & 0.046 \\
\hline $\begin{array}{l}\text { Disposition for } \\
\text { strategically } \\
\text { thinking } \\
\text { and planning }\end{array}$ & $\begin{array}{l}\text { Before } \\
\text { After }\end{array}$ & $\begin{array}{l}3.82 \\
4.73 \\
\end{array}$ & $\begin{array}{l}0.55 \\
0.79 \\
\end{array}$ & $\begin{array}{c}4 \\
5.2 \\
\end{array}$ & $\begin{array}{l}0.55 \\
0.66 \\
\end{array}$ & $\begin{array}{c}3.93 \\
5.3\end{array}$ & $\begin{array}{l}0.61 \\
0.75\end{array}$ & $31.04 * *$ & 0.18 \\
\hline $\begin{array}{l}\text { Disposition for } \\
\text { intellectual } \\
\text { cautiousness }\end{array}$ & $\begin{array}{l}\text { Before } \\
\text { After }\end{array}$ & $\begin{array}{l}4.29 \\
5.13 \\
\end{array}$ & $\begin{array}{c}0.5 \\
0.64 \\
\end{array}$ & $\begin{array}{l}4.39 \\
5.36 \\
\end{array}$ & $\begin{array}{l}0.66 \\
0.64\end{array}$ & $\begin{array}{l}4.42 \\
5.49 \\
\end{array}$ & $\begin{array}{l}0.59 \\
0.53 \\
\end{array}$ & $10.03 * *$ & 0.066 \\
\hline $\begin{array}{l}\text { Disposition for } \\
\text { the search of } \\
\text { causes or } \\
\text { rationalization } \\
\text { and evaluation }\end{array}$ & Before & 4.03 & 0.53 & 5.18 & 0.65 & 4.23 & 0.69 & $7.73 * *$ & 0.052 \\
\hline $\begin{array}{l}\text { Disposition for } \\
\text { meta-cognitivity }\end{array}$ & $\begin{array}{l}\text { Before } \\
\text { After }\end{array}$ & $\begin{array}{l}4.04 \\
4.81\end{array}$ & $\begin{array}{l}0.53 \\
0.68\end{array}$ & $\begin{array}{l}4.28 \\
5.27\end{array}$ & $\begin{array}{l}0.67 \\
0.72\end{array}$ & $\begin{array}{c}4.27 \\
5.4\end{array}$ & $\begin{array}{l}0.73 \\
0.67\end{array}$ & $19.19 * *$ & 0.12 \\
\hline
\end{tabular}

$(* *) p<.01$

\section{Further Findings}

More than half the students (56.7\%) reported having previously experienced taking internet ecourses, while $43.3 \%$ had never experienced e-courses before. From the students who reported experience with e-courses, $44.4 \%$ reported having taken 1-2 courses, and a similar percentage of the students took 3-4 courses. Few students participated in more than 4 e-courses. $63.5 \%$ of the students reported having participated in other 'high learn' e-courses during the year the research was conducted, as opposed to $36.5 \%$ who participated in just one e-course.

From the students who reported participation in more e-courses throughout the year, $65.8 \%$ took 1-2 courses, and $21.3 \%$ reported participation in 3-4 courses. From the participants, $39.9 \%$ pointed out that their e-course was mandatory, whereas $49.6 \%$ enrolled electively to the course. Only 
$4.3 \%$ enrolled to the course due to recommendation, while $6.1 \%$ noted other reasons. Most of the students $(83.5 \%)$ reported having logged on to the course system for studying purposes mainly from home, $14.4 \%$ mainly from the university, while only $2.1 \%$ logged on from work.

Close to two thirds of the students $(65.5 \%)$ reported that in their e-course there were also face to face meetings in class, while $34.5 \%$ noted that in their course there were no frontal meetings in class. $42.7 \%$ of the students would have preferred having more frontal classes in the e-course, as opposed to $57.3 \%$ who noted having no preference for more frontal classes.

As for their academic performance in general, $52.6 \%$ estimated that there won't be any difference in their achievements in the e-course compared to other courses, about $8.4 \%$ estimated getting a relatively low score in the e-course, whereas 39\% estimated getting a higher score in the e-course than in their other courses. More than two thirds of the students $(68.8 \%)$ reported being pleased with the e-course, as opposed to $20 \%$ who were not pleased, and the rest $(11.2 \%)$ had no opinion on the subject. Most of the students (73.9\%) stated wanting to take more e-courses throughout their studies, while two thirds $(66 \%)$ stated that they will recommend the e-courses they took to their friends, as opposed to $11.2 \%$ who stated that they will not recommend the course.

\section{Discussion}

Lacking the tools of direct thinking measurements, the study's findings are based on the students' reports in the questionnaires. The analysis of the findings shows that there is a significant statistic effect of studying in an e-environment on the changing of intellectual thinking dispositions in all seven measurements of the thinking dispositions. This effect, on all seven thinking dispositions in different degrees of positive intensity, is evident in the four pedagogical and technological variables tested in the research. The findings obtained in all four variables clearly show that the more positive the student's evaluation of the teaching method in the e-course the greater the change was in their thinking dispositions; the more positive view they had on the tasks and assignments, the greater the change was in their thinking dispositions; the higher the degree of use of representation and visualization tools in the e-course was, the greater the change was in the students' thinking dispositions; and the higher the students' ranked the teacher's feedback the greater the change was in the thinking dispositions. Therefore, studying in an e-environment contributes to a change in thinking dispositions, and thus promotes intellectual thinking patterns among students.

The results of our study show that the technological tools of the e-environment were designed and utilized well and therefore were effective tools to the change in thinking dispositions. The use of digital presentation and display tools, such as presentations, documents, charts, audio files, videos; informational work online, for example, locating and evaluating information sources online, visiting websites and links; studying with the use of information technologies, especially forums, discussion boards and chat, also contributed to the change in thinking dispositions. Also, it was found that the pedagogical components on the teaching and studying process, such as the remote teaching method, asynchronous studying, self-study, studying with classmates, online study materials, had a positive effect on the students' thinking dispositions. Online research tasks, which require procedures of processing information and that encourage thinking, and demanding study tasks, which pose a challenge and creates interest, contributed their share to the change in thinking dispositions. The teacher's feedback in the e-course contributed particularly the change in the seven thinking dispositions in terms of speed, efficiency, motivation, understanding, and thinking encouragement.

These results show quite clearly that there is a pedagogical justification to the incorporation of the internet in the traditional teaching and studying processes (Beller \& Or, 2001; Salomon, 2000; Salomon \& Perkins, 1996). Wise planning and clever implementation of technological tools in studying, communicating, and information management in e-courses can contribute not only to 
the betterment of the teaching process, but also to enhance the teaching process and bring on significant changes in the thinking dispositions (Hannum, 2000; Insung, 2001).

Furthermore, the e-teaching and studying methods are mostly based on constructive philosophical and psychological principles. According to these principles studying is a cognitive, social, and cultural process, during which the student creates for himself his information, understanding, and perceptions about social and cultural situations while using construction, dialogue, mediation, balance, reflection, meta-cognition, and research processes (Brooks \& Brooks, 1993; Fosnot, 1996; Perkins, 1999). Also, constructive pedagogy focuses on the student and sees him as a learner who is independent, active, has choice privilege and responsibility, self-disciplined and highly motivated, with autonomy to decide his studying process and organize his study timetable (Harmon \& Hirum, 1996; Hirum, 1999; Tolmie \& Boyle, 2000). The finding of our study confirms the theoretical rationales that stand at the core of effective studying, and their practical implementations in tested courses proved extremely efficient to the intellectual change of thinking dispositions.

\section{Conclusions}

In the tested e-courses some of the students reported a change in all their seven thinking dispositions after participating in the e-course, in accordance to the many and diverse opportunities the studying in an e-environment has provided. Other students reported a change in their thinking dispositions in more specific occasions of the studying, but in a more partial and less even form. These changes, in every one of the thinking dispositions, express the special behavioral norm that is unique to each disposition and the rules to intellectual behavior that derive from it.

This and more, the students' reference to the e-course studying as an integral and inseparable part of the academic teaching process happening in the campus is a significant achievement for their studying methods. The students' achievements in the e-courses they participated in, their satisfaction from the e-learning, their expressing of their wish to participate in more virtual online courses, their report of recommending to their friends this studying method and their intellectual change in thinking clearly show not only the successful integration of the e-teaching and studying method in academic courses, but also its possibility as a worthy substitute for the traditional academic teaching. Having said this, we'll also say that, like every other teaching environment, the eenvironment doesn't suit all the students, even if they are students in higher education institutions.

In light of the above, our conclusion is that studying in an e-environment online, which includes studying with technological applications in digital formats, student oriented constructive strategic teaching and study activities based on web resources, creating techno-pedagogic mechanism, that the intelligent mix may contribute to the change in thinking dispositions in a way that promotes intellectual thought patterns. The study's conclusion raised more study angles that are worthy of being researched, such as further aspects of thinking theories of intelligence in different eteaching and studying contexts; differential testing of the e-tools and means which influence the thinking dispositions; and a testing of the teaching actions, the e-tasks and assignments that are appropriate for developing each one of the seven dispositions.

\section{Summary}

In this study we intended to examine the influence of the pedagogical and technological components of studying in an e-environment on the thinking dispositions of students in academics. We found that in the e-courses there is an interactive system of relations between a numbers of elements that work together: the e-environment, study technologies, the teacher's activity, and the teaching process and its elements. These components worked well together and brought on a change in the students' thinking dispositions in a functionally balanced and complete way. The e- 
environment allowed an innovative and challenging scholastic platform to the change of thinking dispositions; the digital technology contributed to the development of effective thinking; lastly the constructive teaching and studying method in the courses encouraged the development of intellectual thinking and behavior.

The rapid development of technological applications in an e-study environment enhances the need to check their influence of the thinking mechanisms, its processes and patterns regularly. In our opinion, there is a great significance to the creation of the right combination between qualitative content, pedagogical rationale, and a steady and comfortable technical platform to use in courses studied in an e-environment - together they create a pedagogical-technological mechanism that has the power to make an intellectual change in thinking dispositions. This and more, estudying online creates, not only a new type of study-person, but also a new type of thinkingperson. According to the results of this study and others, we see that it's not only about the adaptation of the student to the new study environment but a conceptual change in a more layered level of thinking. The change from the frontal in-class studying to the virtual environment creates changes in the students' thinking mechanisms in two ways: one, following the new cognitive demands that are required from the student in a rich and diverse technological environment; the other, the web based teaching tasks and assignments that are typical of the new study environment, its components and processes. As a result of the web studying process, the e-student builds his thinking in a different way than the student that studies in class from books and workbooks.

In light of the development of the research area and in light of the expanding online reality in the academics, we offer to focus on motivational factors, teaching processes, study tasks, research assignments, and information literacy that affect the students' thinking dispositions. Also, it is advised to check the degree of effect of technological tools and applications for managing studying in an e-environment on the student's thinking. Looking at different aspects in e-courses may shed more light on the components that influence the thinking and can be used as a solid base to the success of the student. The dynamic changes in the e-courses' questions the things we know today. In view of this, it seems more challenges are still ahead.

\section{References}

Alexander, G. (2004). Hypertext-a new technology or other literacy? Script Literacy: Research, Study and Action, 8-7 [Online] (In Hebrew). Retrieved: 01.03.2006 from http://www.scriptil.org/tree.asp?cat=12

Anderson, J. R. (1983). The architecture of cognition. Cambridge, MA: Harvard University Press.

Barell, J. (1991). Teaching for thoughtfulness: Classroom strategies to enhance intellectual development. New York: Longman.

Baron, J. B. (1985). Rationality and intelligence. New York: Cambridge University Press.

Baron, J. B. (1987). Being disposed to thinking: A typology of attitudes and dispositions related to acquiring and using thinking skills. Boston, MA: The University of Massachusetts, Critical and Creative Thinking Program.

Beller, M., \& Or, A. (2001). Virtual learning is Exists reality. Academia: Journal of the University Heads Committee, 9, 27-34.

Ben-Ami, Y. (2007). Digital knowledge technologies: The extension of native cognition or a qualitative change? Doctoral Dissertation, School of Education, Tel-Aviv University (In Hebrew).

Bouhnik, D., \& Carmi, G. (2006). Thinking styles of students on virtual learning course. Talpiyot: Academic college of education yearbook 13-14, 2006, pp. 221-235 (In Hebrew).

Brett, C. (2006, May). Why reading matters even more in the digital age. Educational Computing Organization of Ontario Annual Conference, Toronto. Retrieved: February 6, 2007, from

http://grail.oise.utoronto.ca/cbrett/archives/ECOO2006Reading.ppt 
Brooks, G. J., \& Brooks, M. G. (1993). In search of understanding: The case for constructivist classrooms. Alexandria, VA: ASCD.

Brunken, R., Plass, J. L., \& Leutner, D. (2003). Direct measurement of cognitive load in multimedia learning. Educational Psychologist, 38(1), 53-61.

Cavanaugh, M. A., Milcovich, G. T., \& Tang, J. (2000). The human and technical dimensions of Multimedia Distance Learning (MDL): A study of MDL effectiveness in global human resource management class - Working Paper. New York: Cornell University.

Chipman, S. F., Segal, J. W., \& Glaser, R. (Eds.). (1985). Thinking and Learning Skills. Vol. 2: Current research and open questions. Hillsdale, NJ: Lawrence Erlbaum and Associates.

Dabbagh, N. (2002). Using a Web-Based course management tool to support face-to-face instruction. Technology Source, March-April. Retrieved August 11, 2003, from http://media.sabda.org/alkitab1/Pdfs/Dabbagh-UsingaWeb-BasedCourseManagementTooltoSupportFacetoFa.pdf

Dewey, J. (1933). How we think. Lexington, Mass: Heath.

Dweck, C. S. \& Bempechat, J. (1983). Children's theories of intelligence: Consequences for learning. In: S. G. Paris, G. M. Olson \& H. W. Stevenson (Eds.), Learning and motivation in the classroom (pp. 239256). Hillsdale, NJ: Lawrence Erlbaum Associates.

Easton, S. S. (2003). Clarifying the instructor's role in online distance learning. Communication Education, $52(2), 87-105$.

Ennis, R. H. (1987). A taxonomy of critical thinking dispositions and abilities. In J. B. Baron \& R. S. Sternberg (Eds.), Teaching thinking skills: Theory and practice (pp. 9-26). New York: W. H. Freeman.

Ennis, R. H. (1989). Critical thinking and subject specificity: Clarification and needed research. Educational Researcher, 18, 4-10.

Eshet-Alkalai, Y. (2004). Digital literacy: A conceptual framework for survival skills in the digital era. Journal of Educational Multimedia and Hypermedia, 13(1), 93-106. Retrieved November 14, 2005, from http://www.openu.ac.il/Personal_sites/Yoram-Eshet/Digital-literacy2004-JEMH.pdf

Feuerstein, R. (1980). Instrumental enrichment: An intervention program for cognitive modifiability. Baltimore, MD: University Park Press.

Fitzpatrick, R. (2001). Is distance education better than the traditional classroom? Accelerating the point of information. Retrieved January 10, 2003, from http://www.clearpnt.com/accelepoint/articles/r_fitzpatrick_060101.shtml

Fosnot, C. T. (1996). Constructivism: A psychological theory of learning, In C. T. Fosnot (Ed.), Constructivism: Theory, perspective and practice (pp. 8-13). NY: Teacher College, Columbia University Press.

Gelbart, R. (2000). Improving collaboration in distance learning courses. Unpublished doctoral dissertation, Nova Southeastern University, Ft. Lauderdale.

Gunn, C. (2001, December). Effective online teaching - How far do the frameworks go? In Meeting at the Crossroads: Proceedings of the Annual Conference of the Australasian Society for Computers in Learning in Tertiary Education (ASCLITE, 2001, pp. 235-244), Melbourne, Australia. Retrieved November 14, 2005, from http://www.ascilite.org.au/conferences/melbourne01/pdf/papers/gunnc.pdf

Hannum, W. (2000). Web-based instruction lessons. Carolina: University of North Carolina. Retrieved April 4, 2003, from http://www.soe.unc.edu/edci111/8-98/index_wbi2.htm

Harmon, S., \& Hirum, A. (1996). A systemic approach to the integration of interactive distance learning into education and training. Journal Education for Business, 71, 267-271.

Henry, L. A. (2006). Searching for an answer: The critical role of new literacies while reading on the Internet. The Reading Teacher, 59, 614-627.

Hirumi, A. (1999). Student-Centered, Technology-Rich Learning Environments (SCenTRLE): Operationalizing constructivist approaches to teaching and learning. University of Houston. 
Idan, A. (2001). E-Learning - The future learning and its institutions. Eureka, 14. [Online]. Retrieved May 11, 2004 from http://www.matar.ac.il/eureka/newspaper14/future.asp

Insung, J. (2001). Building a theoretical framework of web-based instruction in the context of distance education. British Journal of Educational Technology, 32(5), 525-534.

Kanai, E. (1999). E-learning models. Studies in Science and Technology, 30, 3-10. (In Hebrew).

Langer, E. (1989). Mindfulness reading. MA: Addison-Wesley.

Lipman, M., Sharp, A., \& Oscanyon, F. (1980). Philosophy in the classroom. Philadelphia: Temple University Press.

Mayer, R. E., \& Moreno, R. (2003). Nine ways to reduce cognitive load in multimedia learning. Educational Psychologist, 38(1), 43-52.

McPeck, J. E. (1981). Critical thinking and education. New York: St. Martin's Press.

Metros, S. E., \& Woolsey, K. (2006). Visual literacy: An institutional imperative. Educause Review, 41(3), 80-81. Retrieved December 24, 2006, from http://www.educause.edu/ir/library/pdf/erm0638.pdf

Mor, N. (2001). Learning concept perception changes as a function of experiencing a new learning environment. Doctoral Dissertation, School of Education, University of Haifa (In Hebrew).

Newell, A. (1990). Theories of cognition. Cambridge, MA: Harvard University Press.

Nickerson, R., Perkins, D. N., \& Smith, E. (1985). The teaching of thinking. Hillsdale. NJ: Lawrence Erlbaum Associates.

Passmore, J. (1967). On teaching to be critical. In R. S. Peters (Ed.), The concept of education (pp. 192212). London: Routledge and Kegan Paul.

Paul, R. W. (1990). Critical thinking: What every person needs to survive in a rapidly changing world. Rohnet Park, CA: Center for Critical Thinking and Moral Critique, Sonoma State University.

Perkins, D. (1999). The many faces of constructivism. Educational Leadership, 57(3), 6-11.

Perkins, D., Jay, E., \& Tishman, S. (1993). Beyond abilities: A dispositional theory of thinking. MerrillPalmer Quarterly, 39(1), 1-21.

Resnick, M. (2002). Rethinking learning in the digital age. In G. Kirkman (Ed.), The global information technology report: Readiness for the networked world (pp. 32-37). Oxford University Press.

Rimor, R., \& Kozminsky, E. (2003). An analysis of the reflections of students in online courses. Research Report for Burda Center for Innovative Communications. [Online]. Retrieved December 26, 2008, from http://burdacenter.bgu.ac.il/publications/finalReports2001-2002/Rimor.pdf

Salomon, G. (1983). The differential investment of mental effort in learning from different sources. Educational Psychologist, 18, 42-50.

Schrag, F. (1988). Thinking in school and society. New York: Routledge.

Salomon, G. (2000). Technology and education in the information age. University of Haifa. (In Hebrew).

Salomon, G., \& Perkins, D. N. (1996). Learning in wonderland: What computers really offer to education? In S. Kerr (Ed.), Technology and the future of education (pp. 111-130). NSSE Yearbook. Chicago: University of Chicago Press.

Siegel, H., (1988). Educating reason: Rationality, critical thinking, and education. New York: Routledge.

Sternberg, R. (1985). Beyond IQ: A triarchic theory of human intelligence. Cambridge, MA: Cambridge University Press.

Sweller, J. (2005). Implications of cognitive load theory for multimedia learning. In R. Mayer (Ed.), Cambridge handbook of multimedia learning (pp.19-30). New York: Cambridge University Press. 
Tishman, S., Perkins, D. N., \& Jay, E. (1995). The thinking classroom: Learning and teaching in a culture of thinking. Needham, MA: Allyn \& Bacon.

Tolmie, A., \& Boyle, J. (2000). Factors influencing the success of computer mediated communication (CMC) environments in university teaching: A review and case study. Computers \& Education, 34, 119-140.

Tyler-Smith, K. (2006). Early attrition among first time e-learners: A review of factors that contribute to drop-out, withdrawal and non-completion rates of adult learners undertaking e-learning programs. JOLT: Journal of Online Teaching and Learning, 2(2). Retrieved December 10, 2006, from http://jolt.merlot.org/Vol2_No2_TylerSmith.htm

Wadmany, R., Rimor, R., \& Rozner, E. (2011). The relationship between attitude, thinking and activity of students in an e-learning course. REM-Research on Education and Media, 3(1).

Whipp, J. L., \& Chiarelli, S. (2004). Self-regulation in a Web-Based course: A case study. Educational Technology Research and Development, 52(4), 5-22.

\section{Biographies}

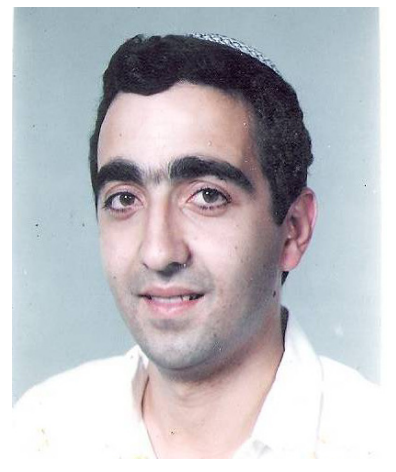

Dr. Dan Bouhnik is a faculty member in the Information Science department in Bar Ilan University (BIU) and in the Computer Science department in Jerusalem College of Technology (JCT) in Israel. He is the author of a number of books used for teaching Advanced Computer Sciences and his professional interests include virtual learning and its effect on the thinking process.

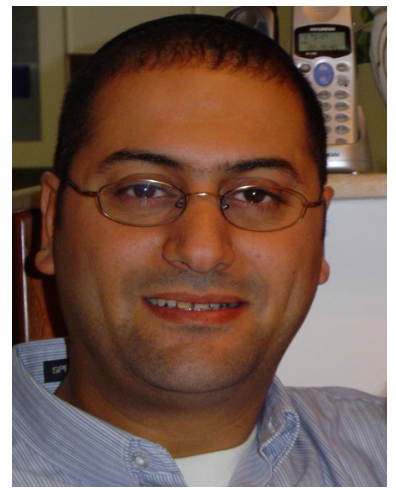

Dr. Golan Carmi is a faculty member in the Department of Accounting \&Information Systems in the Jerusalem College of Technology and is the head of Information Technology field. His professional interests include the introduction of information systems as tools of accounting decision making. 